\title{
Trends in body mass index and prevalence of obesity in Swedish men 1980-89
}

\author{
Alicja Kuskowska-Wolk, Reinhold Bergström
}

\begin{abstract}
Study objective-To assess changes in the body mass index (BMI, weight $(\mathrm{kg}) / \mathrm{height}^{2}$ $\left(\mathrm{m}^{2}\right)$ and in the prevalence of obesity in Swedish men during the 1980 s.

Design-Data from two successive cross sectional surveys were used.

Setting-The whole of Sweden.

Participants-Subjects included in the analyses were 7055 men from a 1980-81 survey (response rate $83 \cdot 4 \%$ ) and 6081 men from a 1988-89 survey (response rate $79 \%$ ). Men were aged 16-84 years and were a representative sample of Swedish males. Measurements and main results-The results were based on self reported weight and height obtained during interview. After adjustment for sociodemographic variables, a significant increase in the mean BMI of the entire population of men was found between $1980-81$ and $1988-89\left(0.23 \mathrm{~kg} / \mathrm{m}^{2} ; \mathrm{p}<0 \cdot 001\right)$, with a particularly large increase in the 25-34 year age group $\left(0.45 \mathrm{~kg} / \mathrm{m}^{2} ; \mathrm{p}<0.0001\right)$ which corresponds to 1.4 $\mathrm{kg}$ for a man $180 \mathrm{~cm}$ tall). In manual workers this value was $0.25 \mathrm{~kg} / \mathrm{m}^{2} \quad(p<0.0005)$. This increase was also reflected by a significant relative increase in the prevalence of the combination of overweight and obesity (BMI >25 $\mathrm{kg} / \mathrm{m}^{2}$ ) of about $19 \%$ (odds ratio $=1 \cdot 19,95 \%$ confidence intervals: $1 \cdot 09,1 \cdot 29)$.
\end{abstract}

Conclusions-During the 1980 s the mean BMI and the prevalence of overweight and obesity among adult Swedish men increased.

f Epidemiol Community Health 1993; 47: 103-108

Information programmes and treatment of obesity are common in many countries. The effectiveness of these preventive methods in an entire population-that is, in different sociodemographic groups-is of great interest since obesity is associated with a number of medical and psychosocial complications. ${ }^{12}$ Higher rates of mortality among obese subjects have also been reported. ${ }^{3-5}$ It is therefore important to investigate trends over time in the body mass index (BMI) and in the prevalence of obesity in different countries. Changes in the BMI and the prevalence of obesity over time in men have recently been investigated in the USA, ${ }^{6-10}$ Italy, ${ }^{11}$ Finland, ${ }^{12}$ Denmark, ${ }^{13} 14$ The Netherlands, ${ }^{15}$ and Czechoslovakia. ${ }^{16}$ In Sweden, there is no information on these trends. Earlier studies have reported an inverse relation between sociodemographic status and obesity in women. ${ }^{17-30}$ The associations found between sociodemographic factors and obesity in men, however, have been weaker, more variable, and less consistent. ${ }^{6} 18-22$ 24-29 $31-35$

Data from two successive cross sectional surveys were used to study changes in the BMI and prevalence of obesity in Swedish men between 1980-81 and 1988-89. Adjustments were made for possible differences in age, education, socioeconomic class, geographical region, and nationality, between these two study periods. The relations between sociodemographic variables and BMI and the prevalence of obesity are also presented.

\section{Methods}

Data from two national surveys on living conditions-Undersökning av Levnadsförhållande (ULF) 1980-81 and ULF 1988-89- were used for the analyses. These surveys were designed and conducted by Statistics Sweden (the official statistical organisation). Questions about weight and height were included among about 200 other questions covering many aspects of living conditions. Nationally representative samples of Swedish men aged 16-84 years who resided permanently in Sweden were chosen for each survey.

The procedure for data collection was the same in $1980-81$ and $1988-89$, and most of the data were collected during a personal visit by an inverviewer. Some interviews were performed by telephone when there was no reply or when the interviewee requested it.

Weight and height were self reported by subjects, without an objective check by the interviewer, although the latter would have reacted in the event of an obvious discrepancy between the observed stature and the reported values.

The validity and reproducibility of these self reports on weight and height have been studied and previously reported. ${ }^{36-37}$ The response rate in $1980-81$ was $83 \cdot 4 \%$ and in $1988-89$ it was $79 \%$. The number of study subjects, broken down by sociodemographic group and year of the survey, is presented in table I. Details of the surveys are given elsewhere. ${ }^{37}$

We computed the body mass index (BMI) using the widely accepted method of weight $(\mathrm{kg})$ divided by the square of height $\left(\mathrm{m}^{2}\right) \cdot{ }^{38}$ The criteria recommended by the FAO/WHO/UNU expert consultation in 1985 were used to assess the prevalence of obesity in Swedish men. ${ }^{39}$ The cut off points for BMI were as follows:

$\mathrm{BMI}=25-30 \mathrm{~kg} / \mathrm{m}^{2}$ - overweight (obesity grade
$\mathrm{I}^{40}$ ); BMI $>30 \mathrm{~kg} / \mathrm{m}^{2}$-obesity (obesity grade II and upwards $\left.{ }^{40}\right)$. 
STATISTICAL METHODS

In the analyses with BMI in a continuous form, the standard regression model was used. This model made it possible to estimate the effects of each

Table I Body mass index in nationally representative samples of Swedish men by age group, education, socioeconomic group, region, and nationality for two study periods, 1980-81 and 1988-89 (mean (SD))

\begin{tabular}{|c|c|c|c|c|c|c|}
\hline \multirow[b]{3}{*}{ Characteristics } & \multicolumn{6}{|c|}{ Body mass index $\left(\mathrm{kg} / \mathrm{m}^{2}\right)$} \\
\hline & \multicolumn{3}{|c|}{$1980-81$} & \multicolumn{3}{|c|}{$1988-89$} \\
\hline & No & Mean & $(S D)$ & No & Mean & $(S D)$ \\
\hline $\begin{array}{l}\text { Age group }(\mathrm{y}) \text { : } \\
16-24 \\
25-34 \\
35-44 \\
45-54 \\
55-64 \\
65-74 \\
75-84 \\
\text { Total 16-84 }\end{array}$ & $\begin{array}{r}1117 \\
1291 \\
1195 \\
847 \\
936 \\
785 \\
884 \\
7055\end{array}$ & $\begin{array}{l}22 \cdot 20 \\
23 \cdot 48 \\
24 \cdot 45 \\
25 \cdot 12 \\
25 \cdot 39 \\
25 \cdot 20 \\
24 \cdot 70 \\
24 \cdot 24\end{array}$ & $\begin{array}{l}(2 \cdot 54) \\
(2 \cdot 78) \\
(2 \cdot 92) \\
(3 \cdot 04) \\
(3 \cdot 18) \\
(3 \cdot 19) \\
(3 \cdot 18) \\
(3 \cdot 15)\end{array}$ & $\begin{array}{r}998 \\
1032 \\
1122 \\
976 \\
683 \\
782 \\
488 \\
6081\end{array}$ & $\begin{array}{l}22 \cdot 27 \\
23 \cdot 89 \\
24 \cdot 59 \\
25 \cdot 23 \\
25 \cdot 69 \\
25 \cdot 30 \\
24 \cdot 64 \\
24 \cdot 41\end{array}$ & $\begin{array}{l}(2.76) \\
(2.85) \\
(3.02) \\
(3.19) \\
(3.33) \\
(3.20) \\
(3.28) \\
(3.25)\end{array}$ \\
\hline $\begin{array}{l}\text { Education: } \\
\text { Elementary school, } \leq 9 \text { y } \\
\text { High school, 10-11 y } \\
\text { After high school 12-14 y } \\
\text { University, >14 y } \\
\text { Unspecified }^{\star}\end{array}$ & $\begin{array}{r}2719 \\
1580 \\
1417 \\
449 \\
884\end{array}$ & $\begin{array}{l}24 \cdot 49 \\
24 \cdot 09 \\
23 \cdot 87 \\
23 \cdot 48 \\
24 \cdot 70\end{array}$ & $\begin{array}{l}(3 \cdot 41) \\
(3 \cdot 00) \\
(2 \cdot 77) \\
(2 \cdot 73) \\
(3 \cdot 18)\end{array}$ & $\begin{array}{r}2254 \\
1754 \\
1506 \\
556 \\
-\end{array}$ & $\begin{array}{l}24 \cdot 62 \\
24 \cdot 48 \\
24 \cdot 25 \\
23 \cdot 74 \\
-\end{array}$ & $\begin{array}{l}(3 \cdot 50) \\
(3 \cdot 28) \\
(2 \cdot 95) \\
(2 \cdot 73) \\
-\end{array}$ \\
\hline $\begin{array}{l}\text { Socioeconomic group: } \\
\text { Manual workers } \\
\text { Junior salaried employees } \\
\text { Intermediate salaried employees }\end{array}$ & $\begin{array}{r}3306 \\
541 \\
904\end{array}$ & $\begin{array}{l}24 \cdot 51 \\
24 \cdot 31 \\
24 \cdot 11\end{array}$ & $\begin{array}{l}(3 \cdot 18) \\
(3 \cdot 13) \\
(2 \cdot 78)\end{array}$ & $\begin{array}{r}2698 \\
573 \\
874\end{array}$ & $\begin{array}{l}24 \cdot 72 \\
24 \cdot 45 \\
24 \cdot 22\end{array}$ & $\begin{array}{l}(3.38) \\
(2.94) \\
(2.98)\end{array}$ \\
\hline $\begin{array}{l}\text { Senior salaried employees and } \\
\text { self employed professionals } \\
\text { Farmers } \\
\text { Entrepreneurs } \\
\text { Students }\end{array}$ & $\begin{array}{l}699 \\
593 \\
427 \\
464\end{array}$ & $\begin{array}{l}24 \cdot 01 \\
24 \cdot 87 \\
25 \cdot 00 \\
21 \cdot 55\end{array}$ & $\begin{array}{l}(2 \cdot 79) \\
(3 \cdot 23) \\
(3 \cdot 12) \\
(2 \cdot 38)\end{array}$ & $\begin{array}{l}730 \\
505 \\
213 \\
425\end{array}$ & $\begin{array}{l}24 \cdot 30 \\
25 \cdot 16 \\
25 \cdot 21 \\
21 \cdot 75\end{array}$ & $\begin{array}{l}(2 \cdot 91) \\
(3 \cdot 18) \\
(3 \cdot 15) \\
(2 \cdot 63)\end{array}$ \\
\hline $\begin{array}{l}\text { Region: } \\
\mathrm{H}_{1} \text { Stockholm } \\
\mathrm{H}_{2} \text { Gothenburg and Malmö } \\
\mathrm{H}_{3} \text { Large municipalities } \\
\mathrm{H}_{4} \text { Southern/central Sweden, excluding } 1-3 \\
\mathrm{H}_{5} \text { Northern densely populated area } \\
\mathrm{H}_{6} \text { Northern sparsely populated area }\end{array}$ & $\begin{array}{r}1192 \\
933 \\
2201 \\
1676 \\
547 \\
506\end{array}$ & $\begin{array}{l}23 \cdot 75 \\
24 \cdot 34 \\
24 \cdot 30 \\
24 \cdot 41 \\
24 \cdot 18 \\
24 \cdot 39\end{array}$ & $\begin{array}{l}(3 \cdot 10) \\
(3 \cdot 28) \\
(3 \cdot 19) \\
(3 \cdot 14) \\
(2 \cdot 98) \\
(2 \cdot 91)\end{array}$ & $\begin{array}{r}986 \\
850 \\
2012 \\
1374 \\
443 \\
416\end{array}$ & $\begin{array}{l}24 \cdot 00 \\
24 \cdot 34 \\
24 \cdot 32 \\
24 \cdot 68 \\
24 \cdot 43 \\
25 \cdot 05\end{array}$ & $\begin{array}{l}(3 \cdot 34) \\
(3 \cdot 36) \\
(3 \cdot 06) \\
(3 \cdot 28) \\
(3 \cdot 26) \\
(3 \cdot 44)\end{array}$ \\
\hline $\begin{array}{l}\text { Nationality: } \\
\text { Native born Swedish } \\
\text { Second generation immigrants } \\
\text { Naturalized immigrants } \\
\text { Foreign nationals }\end{array}$ & $\begin{array}{r}6288 \\
242 \\
226 \\
295\end{array}$ & $\begin{array}{l}24 \cdot 25 \\
23 \cdot 32 \\
24 \cdot 67 \\
24 \cdot 27\end{array}$ & $\begin{array}{l}(3 \cdot 12) \\
(3 \cdot 25) \\
(3 \cdot 23) \\
(3.46)\end{array}$ & $\begin{array}{r}5345 \\
276 \\
244 \\
206\end{array}$ & $\begin{array}{l}24 \cdot 40 \\
23 \cdot 86 \\
25 \cdot 02 \\
24 \cdot 63\end{array}$ & $\begin{array}{l}(3.22) \\
(3.35) \\
(3.32) \\
(3.63)\end{array}$ \\
\hline
\end{tabular}

*In the 1980-81 study, men older than 74 years were not asked about their education

Table II Influence of different variables on the body mass index of Swedish men (regression parameter estimates with standard errors).

\begin{tabular}{|c|c|c|c|}
\hline Variables & Estimate & $\begin{array}{l}\text { Standard } \\
\text { error }\end{array}$ & $p$ value \\
\hline Intercept & $22 \cdot 36$ & $0 \cdot 11$ & \\
\hline $\begin{array}{l}\text { Study 1980-91 (ref) } \\
\text { Study } 1988-89\end{array}$ & $0 \cdot 23$ & 0.06 & $0 \cdot 001$ \\
\hline \multicolumn{4}{|l|}{$\begin{array}{l}\text { Age group (y): } \\
16-24(\mathrm{ref})\end{array}$} \\
\hline $25-34$ & 1.21 & $0 \cdot 10$ & 0.0001 \\
\hline $35-44$ & $2 \cdot 07$ & $0 \cdot 10$ & $0 \cdot 0001$ \\
\hline $45-54$ & $2 \cdot 65$ & $0 \cdot 11$ & 0.0001 \\
\hline $55-64$ & $2 \cdot 97$ & 0.11 & 0.0001 \\
\hline $65-74$ & 2.59 & 0.11 & 0.0001 \\
\hline $75-84$ & $1 \cdot 88$ & $0 \cdot 16$ & $0 \cdot 0001$ \\
\hline \multicolumn{4}{|l|}{$\begin{array}{l}\text { Education: } \\
\text { Elementary school, } \leq 9 \text { y (ref) }\end{array}$} \\
\hline $\begin{array}{l}\text { Elementary school, } \leq 9 \text { y (ref) } \\
\text { High school, } 10-11 \text { y }\end{array}$ & $-0 \cdot 10$ & & \\
\hline After high school, $12-14$ y & $-0 \cdot 27$ & 0.08 & 0.0007 \\
\hline University, $>14$ y & $-0 \cdot 96$ & $0 \cdot 13$ & $0 \cdot 0001$ \\
\hline \multirow{2}{*}{\multicolumn{4}{|c|}{ Socioeconomic group: }} \\
\hline $\begin{array}{l}\text { Manual workers (ref) } \\
\text { Junior salaried employees }\end{array}$ & & & \\
\hline $\begin{array}{l}\text { Junior salaried employees } \\
\text { Intermediate salaried employees }\end{array}$ & $\begin{array}{l}-0.31 \\
-0.43\end{array}$ & $\begin{array}{l}0.10 \\
0.09\end{array}$ & 0.0001 \\
\hline $\begin{array}{l}\text { Intermediate salaried employees } \\
\text { Senior salaried employees and self employed }\end{array}$ & & & \\
\hline professionals & $-0 \cdot 29$ & $0 \cdot 11$ & 0.0103 \\
\hline Farmers & 0.09 & $0 \cdot 10$ & $0 \cdot 3859$ \\
\hline Entrepreneurs & -0.06 & $0 \cdot 13$ & 0.6101 \\
\hline Students & $-1 \cdot 37$ & $0 \cdot 13$ & $0 \cdot 0001$ \\
\hline \multicolumn{4}{|l|}{$\begin{array}{l}\text { Regions: } \\
\text { H, Stockholm (ref) }\end{array}$} \\
\hline $\begin{array}{l}\mathrm{H}_{1} \text { stocknolm (ren) } \\
\mathrm{H}_{2} \text { Gothenburg and Malmö }\end{array}$ & 0.43 & $0 \cdot 10$ & 0.0001 \\
\hline $\mathrm{H}_{3}$ Large municipalities & 0.35 & 0.08 & 0.0001 \\
\hline $\mathrm{H}_{4}$ Southern/central Sweden, excluding 1-3 & $0 \cdot 43$ & 0.09 & 0.0001 \\
\hline $\mathrm{H}_{5}$ Northern densely populated areas & 0.38 & $0 \cdot 12$ & 0.0011 \\
\hline $\mathrm{H}_{6}$ Northern sparsely populated areas & $0 \cdot 62$ & $0 \cdot 12$ & 0.0001 \\
\hline \multicolumn{4}{|l|}{$\begin{array}{l}\text { Nationality: } \\
\text { Native born Swedish (ref) }\end{array}$} \\
\hline $\begin{array}{l}\text { Native born Swedish (ref) } \\
\text { Second generation immigrants }\end{array}$ & 0.27 & 0.14 & \\
\hline Naturalised immigrants & $0 \cdot 30$ & 0.14 & 0.0355 \\
\hline Foreign nationals & 0.51 & $0 \cdot 14$ & 0.0002 \\
\hline
\end{tabular}

$($ ref $)=$ reference group explanatory variable-study period, age, education, socioeconomic group, region, and ethnic origins - after adjustment for the effects of the other variables. The explanatory variables were used in categorical or categorised form. In the regression models, each variable was represented by suitably chosen dummy variables in such a way that one of the categories of each variable served as the reference category (period 1980-81, age group 16-24 years, etc as shown in table II). The estimated parameters show the differences with regard to this reference group. Thus, the parameter 0.23 in table II suggests that after adjustment for the effects of other variables the BMI was 0.23 units higher in the time period 1988-89 than in 1980-81.

In the analyses of the proportion of overweight and obesity, the logistic regression model, estimated by the maximum likelihood method, was used. If the proportion of overweight and obesity (or obesity only) is represented by $\mathrm{P}$, this model assumes that the logarithm of the odds $(\mathrm{P} /(1-\mathrm{P}))$ of being, for example, obese is a linear function of the explanatory variables. From the estimated parameters of this model, odds ratios (ORs) were computed.

The OR of, for example, obesity in 1988-89 compared with $1980-81$ is defined as $\left(P_{1} /\left(1-P_{1}\right)\right) /$ $\left(\mathrm{P}_{0} /\left(1-\mathrm{P}_{0}\right)\right)$ where $\mathrm{P}_{0}$ and $\mathrm{P}_{1}$ represent the risks of being obese in 1980-81 and 1988-89, respectively. The $O R$ is a measure of the relative risk (RR) of being obese and is close to the $R R$ when the absolute risks are reasonably small. When the $R R$ is larger than 1 , the $O R$ is always larger than the $\mathrm{RR}$, and for large absolute risks the difference can be considerable (with $P_{1}=0.5$ and $P_{0}=0.4$ the $R R=1.25$ and the $O R=1.50$ ) This should be kept in mind when the $O R$ values are interpreted. In very general terms the OR of $1 \cdot 15$

Table III Effect of the time period on the body mass index (BMI) of Swedish men in different age groups after adjustment for the effect of education level, socioeconomic group, region, and nationality. The intercept shows the mean BMI $\left(\mathrm{kg} / \mathrm{m}^{2}\right)$ for an individual in the reference group in 1980-81. The slope parameter shows the difference in BMI between 1980-81 and 1988-89.

\begin{tabular}{ccccl}
\hline Age group $(y)$ & Intercept & $(S E)$ & Slope & $(S E)$ \\
\hline $16-24$ & $22 \cdot 27$ & $(0 \cdot 20)$ & $-0 \cdot 03$ & $(0 \cdot 12)$ \\
$25-34$ & $23 \cdot 62$ & $(0 \cdot 21)$ & $0 \cdot 45$ & $(0 \cdot 12)^{\star}$ \\
$35-44$ & $25 \cdot 02$ & $(0 \cdot 20)$ & $0 \cdot 23$ & $(0 \cdot 12)$ \\
$45-54$ & $25 \cdot 00$ & $(0 \cdot 24)$ & $0 \cdot 21$ & $(0 \cdot 15)$ \\
$55-64$ & $24 \cdot 87$ & $(0 \cdot 24)$ & $0 \cdot 27$ & $(0 \cdot 16)$ \\
$65-74$ & $24 \cdot 89$ & $(0 \cdot 26)$ & $0 \cdot 14$ & $(0 \cdot 16)$ \\
$75-84$ & $24 \cdot 34$ & $(0 \cdot 27)$ & $0 \cdot 16$ & $(0 \cdot 21)$ \\
Total 16-84 & $24 \cdot 37$ & $(0 \cdot 09)$ & $0 \cdot 26$ & $(0 \cdot 06)^{\star}$ \\
\hline
\end{tabular}

${ }^{\star} \mathrm{p}<0.0001$

Table IV Effect of the time period on the body mass index (BMI) of Swedish men in different socioeconomic groups after adjustment for the effect of age, education, region, and nationality. The intercept shows the mean $B M I$ for an individual in the reference group in 1980-81. The slope parameter shows the difference in BMI between 1980-81 and 1988-89.

\begin{tabular}{|c|c|c|c|c|}
\hline Socioeconomic groups & Intercept & $(S E)$ & Slope & $(S E)$ \\
\hline Manual workers & $22 \cdot 42$ & $(0 \cdot 17)$ & $0 \cdot 25$ & $(0.09)^{\star}$ \\
\hline or salaried emp & $22 \cdot 46$ & $(0 \cdot 38)$ & 0.08 & $(0 \cdot 18)$ \\
\hline $\begin{array}{l}\text { Intermediate salaried } \\
\text { employees } \\
\text { Senior salaried employees }\end{array}$ & $21 \cdot 75$ & $(0.35)$ & $0 \cdot 21$ & $(0 \cdot 14)$ \\
\hline $\begin{array}{l}\text { Senior salaried employees } \\
\text { and self employed } \\
\text { professionals }\end{array}$ & 23 . & $(0.67)$ & $0 \cdot 29$ & $(0 \cdot 15)$ \\
\hline Farmers & $22 \cdot 60$ & $(0.61)$ & $0 \cdot 28$ & $(0 \cdot 21)$ \\
\hline Entrepreneurs & $24 \cdot 31$ & $(1 \cdot 45)$ & $0 \cdot 20$ & $(0 \cdot 33)$ \\
\hline All socioeconomic groups & $21 \cdot 76$ & $(0 \cdot 10)$ & $0 \cdot 22$ & $(0.06) \dagger$ \\
\hline
\end{tabular}
${ }^{\star} \mathrm{p}<0.005 ; \mathrm{tp}<0.0001$ 
for the period 1988-89 (table VI) means that the RR of becoming obese was $15 \%$ higher in 1988-89 than in 1980-81. When comparing 1980-81 with 1988-89 we shall sometimes use the expression 'trend' in BMI. It should be kept in mind, however, that only two observation points are available and we cannot say whether this is a trend in the true sense of the word.

In all of the regression analyses, the actual sample values were used without any weighting of the observations.

\section{Results}

EIGHT YEAR TRENDS IN MEAN BMI

The crude mean BMI increased by $0.17 \mathrm{~kg} / \mathrm{m}^{2}$ between 1980-81 and 1988-89 (table I). After adjustment for such sociodemographic variables as age, education, socioeconomic group, region, and ethnic origin, the difference increased to 0.23 $\mathrm{kg} / \mathrm{m}^{2}(\mathrm{p}<0.001)$ (table II). This is a $1 \%$ increase over the eight year period. For a man with an average height of $180 \mathrm{~cm}$, the increase corresponds to over $0.7 \mathrm{~kg}$. Table III shows the eight year trends in mean BMI for each age group separately. The greatest increase, seen in the 25-34 year age group, was $0.45 \mathrm{~kg} / \mathrm{m}^{2}$ ( $p<0.0001$ ), which corresponds to $1.4 \mathrm{~kg}$ for a man of average height. In the various socioeconomic groups, workers showed a significantly higher BMI in $1988-89$ than in $1980-81$ $(0.25 \mathrm{~kg} / \mathrm{m} 2 ; \mathrm{p}<0.005)$. The point estimates for the increase in mean BMI among senior salaried employees and farmers were even higher, but they did not reach statistical significance because of the smaller number of observations (table IV).

Table $V$ Prevalence of individuals with body mass index $(B M I)>25 \mathrm{~kg} / \mathrm{m}^{2}$ and with $B M I>30 \mathrm{~kg} / \mathrm{m}^{2}$ in nationally representative samples of Swedish men by age group, education, socioeconomic group, region, and nationality for two study periods 1980-81 and 1988-89.

\begin{tabular}{|c|c|c|c|c|}
\hline \multirow[b]{2}{*}{ Characteristics } & \multicolumn{2}{|c|}{$B M I>25 \mathrm{~kg} / \mathrm{m}^{2}$} & \multicolumn{2}{|c|}{$B M I>30 \mathrm{~kg} / \mathrm{m} 2$} \\
\hline & $\begin{array}{l}1980-81 \\
(\%)\end{array}$ & $\begin{array}{l}1988-89 \\
(\%)\end{array}$ & $\begin{array}{l}1980-81 \\
(\%)\end{array}$ & $\begin{array}{l}1988-89 \\
(\%)\end{array}$ \\
\hline $\begin{array}{l}\text { Age group (y): } \\
16-24 \\
25-34 \\
35-44 \\
45-54 \\
55-64 \\
65-74 \\
75-84 \\
\text { Total 16-84 }\end{array}$ & $\begin{array}{l}11 \cdot 4 \\
23 \cdot 9 \\
35 \cdot 7 \\
45 \cdot 6 \\
50 \cdot 2 \\
49 \cdot 3 \\
41 \cdot 5 \\
35 \cdot 0\end{array}$ & $\begin{array}{l}13 \cdot 1 \\
28 \cdot 7 \\
38 \cdot 5 \\
47 \cdot 7 \\
54 \cdot 0 \\
50 \cdot 3 \\
41 \cdot 0 \\
37 \cdot 4\end{array}$ & $\begin{array}{l}1 \cdot 5 \\
2 \cdot 9 \\
4 \cdot 5 \\
6 \cdot 1 \\
7 \cdot 7 \\
7 \cdot 8 \\
5 \cdot 6 \\
4 \cdot 9\end{array}$ & $\begin{array}{l}1 \cdot 1 \\
2 \cdot 8 \\
6 \cdot 1 \\
7 \cdot 2 \\
8 \cdot 8 \\
7 \cdot 2 \\
6 \cdot 5 \\
5 \cdot 3\end{array}$ \\
\hline $\begin{array}{l}\text { Education: } \\
\text { Elementary school, } \leq 9 \mathrm{y} \\
\text { High school, 10-11 y } \\
\text { After high school 12-14 y } \\
\text { University, }>14 \text { y } \\
\text { Unspecified }\end{array}$ & $\begin{array}{l}40 \cdot 9 \\
31 \cdot 8 \\
29 \cdot 3 \\
22 \cdot 9 \\
41 \cdot 5\end{array}$ & $\begin{array}{l}41 \cdot 8 \\
38 \cdot 9 \\
32 \cdot 9 \\
29 \cdot 0 \\
-\end{array}$ & $\begin{array}{l}6 \cdot 3 \\
4 \cdot 2 \\
3 \cdot 3 \\
2 \cdot 8 \\
5 \cdot 6\end{array}$ & $\begin{array}{l}6 \cdot 9 \\
5 \cdot 0 \\
4 \cdot 8 \\
1 \cdot 8 \\
-\end{array}$ \\
\hline $\begin{array}{l}\text { Socioeconomic group: } \\
\text { Manual workers } \\
\text { Junior salaried employees } \\
\text { Intermediate salaried employees } \\
\text { Senior salaried employees and }\end{array}$ & $\begin{array}{l}38 \cdot 9 \\
34 \cdot 4 \\
31 \cdot 0\end{array}$ & $\begin{array}{l}41 \cdot 1 \\
37 \cdot 1 \\
33 \cdot 3\end{array}$ & $\begin{array}{l}5 \cdot 4 \\
4 \cdot 9 \\
3 \cdot 7\end{array}$ & $\begin{array}{l}6 \cdot 4 \\
5 \cdot 0 \\
3 \cdot 8\end{array}$ \\
\hline $\begin{array}{l}\text { self employed professionals } \\
\text { Farmers } \\
\text { Entrepreneurs } \\
\text { Students }\end{array}$ & $\begin{array}{l}28 \cdot 6 \\
44 \cdot 6 \\
48 \cdot 7 \\
10 \cdot 6\end{array}$ & $\begin{array}{l}35 \cdot 3 \\
47 \cdot 4 \\
52 \cdot 1 \\
13 \cdot 0\end{array}$ & $\begin{array}{l}3 \cdot 3 \\
7 \cdot 9 \\
5 \cdot 9 \\
2 \cdot 0\end{array}$ & $\begin{array}{l}4 \cdot 0 \\
8 \cdot 1 \\
6 \cdot 3 \\
1 \cdot 4\end{array}$ \\
\hline $\begin{array}{l}\text { Region: } \\
\mathrm{H}_{1} \text { Stockholm } \\
\mathrm{H}_{2} \text { Gothenburg } \\
\mathrm{H}_{3} \text { Large municipalities } \\
\mathrm{H}_{4} \text { Southern/central Sweden, excluding } 1-3 \\
\mathrm{H}_{5} \text { Northern densely populated area } \\
\mathrm{H}_{6} \text { Northern sparsely populated area }\end{array}$ & $\begin{array}{l}27 \cdot 6 \\
35 \cdot 9 \\
36 \cdot 3 \\
37 \cdot 1 \\
36 \cdot 1 \\
37 \cdot 4\end{array}$ & $\begin{array}{l}31 \cdot 4 \\
36 \cdot 1 \\
38 \cdot 1 \\
40 \cdot 2 \\
36 \cdot 3 \\
46 \cdot 5\end{array}$ & $\begin{array}{l}4 \cdot 0 \\
5 \cdot 7 \\
5 \cdot 5 \\
4 \cdot 7 \\
3 \cdot 6 \\
4 \cdot 6\end{array}$ & $\begin{array}{l}5 \cdot 2 \\
5 \cdot 5 \\
4 \cdot 2 \\
6 \cdot 2 \\
5 \cdot 6 \\
8 \cdot 2\end{array}$ \\
\hline $\begin{array}{l}\text { Nationality: } \\
\text { Native born Swedish } \\
\text { Second generation immigrants } \\
\text { Naturalised immigrants } \\
\text { Foreign nationals }\end{array}$ & $\begin{array}{l}35 \cdot 1 \\
25 \cdot 2 \\
42 \cdot 0 \\
34 \cdot 6\end{array}$ & $\begin{array}{l}37 \cdot 1 \\
34 \cdot 4 \\
43 \cdot 7 \\
40 \cdot 5\end{array}$ & $\begin{array}{l}4 \cdot 7 \\
4 \cdot 6 \\
7 \cdot 7 \\
6 \cdot 8\end{array}$ & $\begin{array}{l}5 \cdot 4 \\
3 \cdot 1 \\
6 \cdot 6 \\
4 \cdot 2\end{array}$ \\
\hline
\end{tabular}

EIGHT YEAR TRENDS IN THE PREVALENCE OF OVERWEIGHT AND OBESITY

Table $\mathrm{V}$ presents the crude percentages of men with BMI $>25 \mathrm{~kg} / \mathrm{m} 2$ (overweight and obese) and with $\mathrm{BMI}>30 \mathrm{~kg} / \mathrm{m}^{2}$ (obese) in different sociodemographic groups according to the year of the survey. The above mentioned increase in the mean $\mathrm{BMI}$ was also observed in the analyses with $\mathrm{BMI}$ in categorised form. Table VI shows a $19 \%$ relative increase in the prevalence of men with BMI $>25$ $\mathrm{kg} / \mathrm{m}^{2}$ in adult Swedish men over the eight year period. In absolute values, the prevalence of overweight and obesity increased by about $0 \cdot 13 \% /$ year. The greatest relative increase in the prevalence of BMI $>25 \mathrm{~kg} / \mathrm{m}^{2}$ took place in the $25-34$ year age group $(O R=1 \cdot 36,95 \%$ confidence interval (CI): $1 \cdot 12,1.65)$ and among senior salaried employees and self employed professionals $1.41 ; 1 \cdot 10,1.80$ ) (tables VII and VIII). The prevalence of obesity (BMI $>30 \mathrm{~kg} / \mathrm{m}^{2}$ ) was not significantly different in 1988-89 and 1980-81 for any specific age or socioeconomic group.

\section{SOCIODEMOGRAPHIC TRENDS IN BMI AND THE} PREVALENCE OF OBESITY

Tables II and VI show quantitative estimates of these relations. The BMI in men is largely determined by age, the highest mean values occurring in the 55-64 year age group. In this group the prevalence of BMI $>25 \mathrm{~kg} / \mathrm{m}^{2}$ is up to sevenfold higher and the prevalence of obesity up to sixfold higher than in young men 16-24 years of age.

A clear trend is present-- that is, Swedish men with a higher education tend to have a significantly lower BMI. The difference between men with a university degree and those with only an elementary school education amounts to about 1 $\mathrm{kg} / \mathrm{m}^{2}$, which corresponds to $3.2 \mathrm{~kg}$ for a man 180 $\mathrm{cm}$ tall. In the highest education group, the prevalence of BMI $>25 \mathrm{~kg} / \mathrm{m}^{2}$ is about $50 \%$ lower and the prevalence of obesity about $60 \%$ lower than in the elementary education group.

Junior, intermediate, and senior salaried employees and self employed professional men all have a significantly lower BMI than manual workers. The mean BMIs of farmers and entrepreneurs do not differ from those of workers. The prevalence of BMI $>25 \mathrm{~kg} / \mathrm{m}^{2}$ is also significantly lower among junior, intermediate, and senior salaried employees than among manual workers. Obesity occurs significantly less often in intermediate salaried employees. Changes in the BMI with increasing age vary substantially between socioeconomic groups. The mean BMI of senior salaried employees and self employed professional men remains relatively stable throughout life, with the greatest difference, $1.2 \mathrm{~kg} / \mathrm{m}^{2}(\mathrm{p}=0.05)$, in the 55-64 year age group compared with the men aged 16-24 years. In contrast, farmers in the same age group increased their mean BMI by $3.3 \mathrm{~kg} / \mathrm{m}^{2}$ (data not shown in tables).

Compared with men from Stockholm, all other geographical regions in Sweden have significantly higher BMIs. The most striking difference, seen in the northern sparsely populated areas $(0.62$ $\mathrm{kg} / \mathrm{m}^{2}$ ), corresponds to $2 \mathrm{~kg}$ for a man $180 \mathrm{~cm}$ tall. The prevalence of $\mathrm{BMI}>25 \mathrm{~kg} / \mathrm{m}^{2}$ is about $30-40 \%$ higher in all regions other than Stockholm. 
Table VI Prevalence of overweight and obesity (body mass index (BMI) $>25 \mathrm{~kg} / \mathrm{m}^{2}$ ) and obesity $\left(B M I>30 \mathrm{~kg} / \mathrm{m}^{2}\right)$ in nationally representative samples of Swedish men by year of study, age, education, socioeconomic group, region, and nationality after adjustment for the effects of the other variables (odds ratios (OR) with $95 \%$ confidence intervals (CI)).

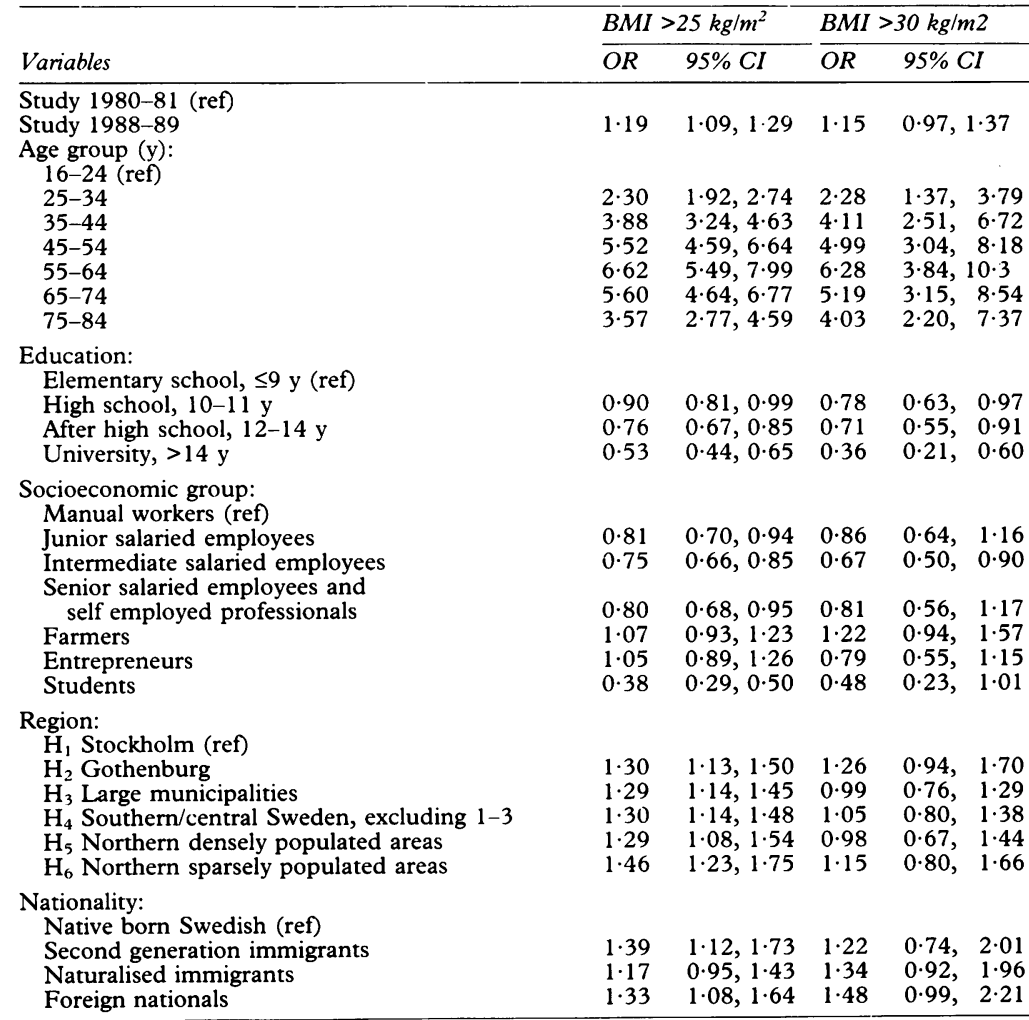

Native born Swedish men have a significantly lower mean BMI (after adjustment for age, education, socioeconomic group, and region) than those of all other ethnic groups living in Sweden. The prevalence of BMI $>25 \mathrm{~kg} / \mathrm{m}^{2}$ among native Swedes is significantly lower than that among second generation immigrants and other ethnic groups.

Finally, it should be pointed out that although we have noted very significant effects in many cases, the regression model presented in table II (including variables such as the study period, age, education, socioeconomic group, region and ethnic origin) explains only $14 \%$ of the variance in BMI among Swedish men $\left(R^{2}=0 \cdot 14\right)$.

\section{Discussion}

Our study has two important features: firstly, a large number of representative subjects, and secondly, available data on many sociodemographic variables that make it possible to adjust for them in the analyses.

\section{TIME TRENDS IN BMI DEVELOPMENT}

According to the data from the two ULF cross sectional surveys, there is a statistically significant increase in the mean BMI among Swedish adult men during the 1980 s when adjusted for age, education, socioeconomic group, region, and ethnic origin. In every age group from 25 years up to 84 years, and among most socioeconomic groups, the mean BMI has increased. Our findings, in general, confirm and extend similar observations made in surveys carried out in the USA and Europe. $^{6} 15$
A report using American data on men aged 35-74 years who participated in four nationwide surveys in 1960-80 (NHES I and III; NHANES I and II) indicated an increase in the mean BMI for all age groups. ${ }^{6}$ No consistent trend was found in men aged 18-34 years from the same surveys. ${ }^{78}$ In the Minnesota Heart Survey the age adjusted mean BMI of men aged 25-59 years increased significantly by $1 \mathrm{~kg} / \mathrm{m}^{2}$ from 1973 to $1987 .{ }^{9} \mathrm{~A}$ significant increase in BMI, adjusted for age and education, was found between 1980 and 1987 in a sample of men aged $25-74$ years $\left(0 \cdot 8 \mathrm{~kg} / \mathrm{m}^{2} /\right.$ year over seven years) from the Minnesota Heart Health Programme. A further analysis of these data indicated that the weight increase was noticeable only in the 30-39 and 50-59 year age groups. ${ }^{10}$

The results from European countries are more heterogeneous. In Italy, the mean BMI of men aged 20-59 years in 1983-84 did not change in relation to the mean BMI of people examined in 1978-79 in the nine communities study. ${ }^{11}$ Three population surveys in eastern Finland, carried out in 1972, 1977, and 1982, each included about 1600 men aged 30-59 years. In men aged 30-39 years, the mean BMI remained stable between 1972 and 1982; in those aged $40-49$ years the mean BMI increased by $1.1 \mathrm{~kg} / \mathrm{m}^{2}$; and in those $50-59$ years of age it increased less noticeably. ${ }^{12} \mathrm{It}$ should be noted that the mean BMIs of Italian and Finnish men were not adjusted for age or other sociodemographic characteristics of the subjects. The 25th, 50th, and 75th centiles for BMI of 18 year old Danish men remained essentially unchanged over 20 years between 1957 and 1976. ${ }^{13}$ Data from two screening projects concerning cardiovascular risk factors were used to investigate trends in BMI in The Netherlands in 1974 and 1986. The mean BMI of 14000 men aged 37-43 years examined in the period 197480 , showed an increase of $0.5 \mathrm{~kg} / \mathrm{m}^{2}$ (adjusted for age and town). In the period 1981-86 there was no change in the mean BMI of 80000 men aged 33-37 years in The Netherlands; however, some regional differences were noted. ${ }^{15}$

TIME TRENDS IN PREVALENCE OF OBESITY

Our findings show that the prevalence of overweight and obesity (defined as BMI $>25 \mathrm{~kg} / \mathrm{m}^{2}$ ) and obesity (BMI $>30 \mathrm{~kg} / \mathrm{m}^{2}$ ) increased consistently in all age and socioeconomic groups of Swedish men during the 1980 s. During a similar period (1980-87) in the upper midwestern region of the USA, the prevalence of obesity, defined as BMI $>30 \cdot 16 \mathrm{~kg} / \mathrm{m}^{2}$ (85th centile at year 1980$)$, increased by $0.6 \% /$ year in men aged $25-74$

Table VII Effect of time period on the prevalence of Table $\left.\mathrm{kg} / \mathrm{m}^{2}\right)$ and of obesity (BMI $>30 \mathrm{kgm}^{2}$ ) in different age groups after adjustment for the effect of education, socioeconomic group, region, and nationality (odds ratios (OR) with $95 \%$ confidence intervals (CI)).

\begin{tabular}{rlllll}
\hline & \multicolumn{2}{c}{$B M I>25 \mathrm{~kg} / \mathrm{m}^{2}$} & & \multicolumn{2}{c}{$B M I>30 \mathrm{~kg} / \mathrm{m}^{2}$} \\
\cline { 2 - 3 } Age group $(y)$ & $O R$ & $95 \% \mathrm{CI}$ & & $O R$ & $95 \% C I$ \\
\hline $16-24$ & 1.13 & $0.85,1.49$ & & 0.81 & $0.35,1.88$ \\
$25-34$ & 1.36 & $1.12,1.65$ & & 1.04 & $0.62,1.75$ \\
$35-44$ & 1.19 & $0.99,1.43$ & & 1.47 & $0.99,2.18$ \\
$45-54$ & 1.16 & $0.96,1.41$ & & 1.19 & $0.80,1.76$ \\
$55-64$ & 1.18 & $0.96,1.45$ & & 1.22 & $0.84,1.77$ \\
$65-74$ & 1.06 & $0.86,1.31$ & & 0.96 & $0.64,1.42$ \\
$75-84$ & 1.11 & $0.85,1.45$ & & 1.35 & $0.81,2.26$ \\
Total 16-84 & 1.20 & $1.11,1.30$ & & 1.17 & $0.99,1.39$ \\
\hline
\end{tabular}


Table VIII Effect of the time period on the prevalence of overweight and obesity (body mass index $\left.(B M I)>25 \mathrm{~kg} / \mathrm{m}^{2}\right)$ and of obesity $\left(B M I 30 \mathrm{~kg} / \mathrm{m}^{2}\right)$ in different socioeconomic groups after adjustment for the effect of age, education, region and nationality (odds ratios (OR) with $95 \%$ confidence intervals (CI)).

\begin{tabular}{|c|c|c|c|c|}
\hline \multirow[b]{2}{*}{ Socioeconomic groups } & \multicolumn{2}{|c|}{$B M I>25 \mathrm{~kg} / \mathrm{m}^{2}$} & \multicolumn{2}{|c|}{$B M I>30 \mathrm{~kg} / \mathrm{m}^{2}$} \\
\hline & $O R$ & $95 \% C I$ & $O R$ & $95 \% C I$ \\
\hline Manual workers & $1 \cdot 15$ & $1 \cdot 02,1 \cdot 29$ & $1 \cdot 23$ & $0.97,1.57$ \\
\hline Junior salaried employees & 1.08 & $0.82,1.43$ & 0.93 & $0.54,1.61$ \\
\hline Intermediate salaried employees & $1 \cdot 21$ & $0.97,1.51$ & $1 \cdot 08$ & $0.63,1.85$ \\
\hline Senior salaried employees and self employed & & & & \\
\hline professionals & 1.41 & $1 \cdot 10,1 \cdot 80$ & $1 \cdot 16$ & $0.65,2.09$ \\
\hline Farmers & $1 \cdot 16$ & $0.88,1.53$ & $1 \cdot 20$ & $0.74,1.95$ \\
\hline Entrepreneurs & $1 \cdot 24$ & $0.80,1.93$ & $1 \cdot 29$ & $0.54,3.05$ \\
\hline Students & $1 \cdot 26$ & $0 \cdot 76,2 \cdot 10$ & 0.42 & $0 \cdot 08,2 \cdot 24$ \\
\hline All socioeconomic groups & $1 \cdot 18$ & $1 \cdot 09,1 \cdot 28$ & $1 \cdot 16$ & $0.97,1.38$ \\
\hline
\end{tabular}

years. ${ }^{10}$ A similar absolute increase (about $4 \%$ over seven years) in the prevalence of obesity, defined as $\mathrm{BMI}=27-30 \mathrm{~kg} / \mathrm{m}^{2},{ }^{15}$ was observed in The Netherlands in 1976-80 among men 37-43 years of age. In Finland, between 1972 and 1982 , an increase in the prevalences of BMI $>25 \mathrm{~kg} / \mathrm{m}^{2}$ and $\mathrm{BMI}>30 \mathrm{~kg} / \mathrm{m}^{2}$ in men were particularly pronounced in the 40-59 years aged group but not in the 30-39 year age group. ${ }^{12}$ In Denmark, the prevalence of obesity $\left(\mathrm{BMI}>30 \mathrm{~kg} / \mathrm{m}^{2}\right.$ ) showed a steep increase in the birth cohorts, beginning in the early 1940 s and levelling off thereafter. ${ }^{13} 14$ The most dramatic increase in the prevalence of obesity among men was reported from Czechoslavakia between 1985 and 1988. The proportion of obese men in the 25-64 year age group rose from $18.5 \%$ to $23.9 \%, \mathrm{p}<0.001 .^{16}$

These data indicate that the mean BMI and the prevalence of obesity generally increased in adult men in both Europe and the United States, with some exceptions. It should be pointed out that in most of the studies information about the BMI was available for only two or three points in time. Moreover, in not all studies were the mean BMI and prevalence of obesity adjusted for differences in age and in the distribution of other sociodemographic parameters in successive surveys. An advantage of the present study was the availability of sociodemographic characteristics which made it possible to adjust for potential effects of confounding variables.

\section{SOCIODEMOGRAPHIC TRENDS}

Our study includes a broader range of age, education, socioeconomic status, geographical region, and ethnic origin than do more limited samples, which tend to be more homogeneous and very often limited to one region only. The results concerning adult Swedish men in nationally representive samples confirm that there is a strong positive association between BMI and the prevalence of obesity in relation to age. This association varies, however, among socioeconomic groups: it is strongest among farmers and very weak among senior salaried employees and self employed professionals. The significant inverse relation between education and socioeconomic group and the BMI in men agrees with a trend among American men. 72935

Native born Swedes living in Stockholm have a lower BMI than those who live in other large municipalities and geographical regions and who are not native Swedes. Our results agree with studies showing differences in the prevalence of obesity between those living in rural and urban environments $^{26}$ and among various ethnic groups. $^{33}$
In summary, there are clear sociodemographic patterns of obesity in various populations. These patterns should be taken into account in planning effective means of preventing and controlling obesity.

1 Van Italie TB. Health implications of overweight and obesity in the United States. Ann Intern Med 1985; 103: 983-8.

Hubert HB, Feinleib M, McNamara PM, Castelli WP

Obesity as an independent risk factor for cardiovascular disease: a 26-year follow-up of participants in the Framingham heart study. Circulation 1983; 67: 968-77.

3 Lew EA, Garfinkel L. Variations in mortality by weight among 750000 men and women, $\mathcal{f}$ Chron Dis 1979; 32: among $7503-76$.

4 Waaler HT. Height, weight and mortality. The Norwegian experience. Acta Medica Scandinazica 1984; (Suppl) 679 $1-56$

5 Linsted K, Tonstad S, Kuzma JW. Body mass index and patterns of mortality among seventh-day adventist men. In f Obes 1991; 15: 397-406.

6 Feinleib M. Epidemiology of obesity in relation to health hazards. Ann Intern Med 1985; 103: 1019-24.

7 Flegal KM, Harlan WR, Landis JR. Secular trends in body mass index and skinfold thickness with socioeconomic factors in young adult men. Am $\mathcal{F}$ Clin Nutr 1988; 48: $544-51$.

8 Harlan WR, Landis R, Flegal KM, Davis CS, Miller ME. Secular trends in body mass in the United States, 1960 1980. Am 7 Epidemiol 1988; 5: 1065-74.

9 Burke GL, Sprafka JM, Folsom AR, Luepker RV, Norsted SW, Blackburn H. Trends in CHD mortality, morbidity $\mathrm{SW}$, Blackburn $\mathrm{H}$. Trends in CHD mortality, morbidity
and risk factor levels from 1960 to 1986: the Minnesota heart survev. Int $\mathcal{F}$ Epidemiol 1989; 3 (suppl 1): S73-81.

10 Shah M, Hannan J, Jeffery RW. Secular trend in body mass index in the adult population of three communities from the upper mid-western part of the USA: the Minnesota heart health program. Int $\mathcal{F}$ Obes 1991; 15: 499-503.

11 Research Group ATS-RF2-OB43 of the Italian National Research Council. Time trends of some cardiovascular risk factors in Italy. Results from the nine communities study. Am $\mathcal{F}$ Epidemiol 1987; 126: 95-103.

12 Jalkanen L, Tuomilehto J, Nissinen A, Puska P. Changes in body mass index in a Finnish population between 1972 and 1982. F Internal Med 1989; 226: 163-70.

13 Sørensen TIA, Price RA. Secular trends in body mass index among Danish young men. Int $\mathcal{F}$ Obes 1990; 14: 411-19.

14 Price RA, Ness R, Sorensen TIA. Changes in commingled body mass index distributions associated with secular trends in overweight among Danish young men. Am f Epidemiol 1991; 133: 501-10.

15 Blockstra A, Kronhout D. Trends in obesity in young adults in The Netherlands from 1974 to 1986. Int $\mathcal{F}$ Obes 1991; 15: 513-521.

16 Skodova Z, Pisa Z, Emrova R et al. Cardiovascular risk factors in the Czech population. Cor Vasa 1991; 33: 114-22.

17 Moore ME, Stunkard AJ, Srole L. Obesitv, social class and mental illness. FAMA 1962; 1981: 962-6.

18 Goldblatt PB, Moore ME, Stunkard AJ. Social factors in obesity. FAMA 1965; 192: 1039-44.

19 Silverstone JT, Gordon RP, Stunkard AJ. Social factors in obesity in London. Practitioner 1969; 202: 682-6.

20 Khosla T, Lowe CR. Obesity and smoking habits by social class. British fournal of Preventive and Social Medicine 1972;

21 Herman MW. Excess weight and sociocultural characteristics. I Am Diet Assoc 1973; 63: 161-4.

22 Baird IM, Silverstone JT, Grimshaw JJ, Ashwell M. Prevalence of obesity in a London borough. Practitioner 1974; 212: 706-14.

23 Rimm I, Rimm A. Association between socioeconomic status and obesity in 59556 women. Prec Med 1974; 3543-72.

24 Garn SM, Clark DC. Economics and fatness. Ecology' of Food and Nutrition 1974; 3: 19-20.

25 Garn SM, Bailey SM, Cole PE, Higgins ITT. Level of education, level of income and level of fatness in adults. $A m$ 7 Clin Nutr 1977; 30: 721-5.

26 Kohrs MB, Wang LL, Eklund D, Paulsen B, O'Neal R. The association of obesity with socio-economic factors in Missouri. Am f Clin Nutr 1979; 32: 2120-8

27 McLean RA, Moon M. Health, obesity and earnings. $A m f$ Public Health 1980; 70: 1006-9.

28 Khoury PR, Morrison JA, Laskarzewski P et al. Relationships of education and occupation to coronary heart disease risk factors in school children and adults: the Princeton School District Study. Am f Epidemiol 1981; 113: 378-95.

29 Jeffery RW, Forster JL, Folsom AR, Luepker RV, Jacobs DR jr, Blackburn $\mathrm{H}$. The relationship between social status and body mass index in the Minnesota heart health program. Int f Obes 1989; 13: 59-67.

30 Flegal KM, Harlan WR, Landis JR. Secular trends in bod mass index and skinfold thickness with socioeconomic factors in young adult women. Am f Clin Nutr 1988; 48: 53543.

31 Rose G, Marmot MG. Social class and coronary heart Rose G, Marmot MG. Socia
disease. BMIf 1981; 45: 13-9.

32 Fehily AM, Phillips KM, Yarnell JWG. Diet, smoking, social class and body mass index in the Caerphily Heart Diseas Study. Am $\mathcal{F}$ Clin Nutr 1984; 40: 827-33. 
33 Ross CE, Mirowsky J. Social epidemiology of overweight: a substantive and methodological investigation. 7 Health Soc Behav 1983; 24: 288-98.

34 Stern MP, Rosenthal M, Haffner SM, Hazuda HP, Franco LJ. Sex difference in the effects of sociocultural status on diabetes and cardiovascular risk factors in Mexican Americans: the San Antonio heart Study. $A m \mathcal{F}$ Epidemiol 1984; 120: 834-51.

35 Jeffery RW, French SA, Forster JL, Spry VM. Socioeconomic status differences in health behaviors related to obesity: the Healthy Worker Project. Int F Obes 1991; 15: 689-96.
36 Kuskowska-Wolk A, Karlsson P, Stolt M, Rössner S. The predictive validity of body mass index based on self- reported weight and height. Int $\mathcal{F}$ Obes 1989; 13: 441-53.

37 Kuskowska-Wolk A, Rössner S. Prevalence of obesity in Sweden: cross-sectional study of a representative adult population. F Intern Med 1990; 227: 241-6.

38 Garrow JS, Webster Y. Quetelet's index $\left(W / H^{2}\right)$ as a measure of fatness. Int $\mathcal{F}$ Obes 1985; 9: 147-53.

39 Joint $\mathrm{FAO} / \mathrm{WHO} / \mathrm{UNU}$ Expert Consultation. Energy and Protein Requirements. Geneva, WHO: 1985. WHO Protein Requirements. Geneva, WHO: 